\title{
Evaluation of the Toxicity of Silver/Silica and Titanium Dioxide Particles in Mammalian Cells
}

\author{
Michele Pittol $^{1 *}$, Daiane Tomacheski ${ }^{1 \mathrm{e} 2}$, Douglas Naue Simões ${ }^{1 \mathrm{e} 2}$, Vanda Ferreira \\ Ribeiro $^{1 \mathrm{e} 2}$, Ruth Marlene Campomanes Santana ${ }^{2}$. \\ ${ }^{l}$ Softer Brasil Compostos Termoplásticos Campo Bom, Rio Grande do Sul, Brazil ${ }^{2}$ PPGE3M, Universidade \\ Federal do Rio Grande do Sul Porto Alegre Brazil
}

\begin{abstract}
The increasing concern over the spread of diseases has lead to a high consumption of antimicrobial additives in the medical and industrial fields. Since these particles can lixiviate from loaded materials, the contact between this additive and mammalian cells can occur during manufacture, use and disposal of the products. Silver on fumed silica $\left(\mathrm{AgNP}_{-} \mathrm{SiO}_{2}\right)$ and titanium dioxide $\left(\mathrm{TiO}_{2}\right)$ can be used as antimicrobial additives that are applied in polymeric formulation. While these additives can inhibit bacteria, fungus and virus proliferation; they may also be harmful to humans. Standard toxicological studies were undertaken using the MTT (3-(4,5-dimethylthiazol-2-yl)-2,5 diphenyltetrazolium bromide), CBPI (cytokinesis-block proliferation index) and micronucleus assay using different sets of additive concentrations. The nanosize of the samples evaluated was confirmed by transmission electronic microscopy. No significant micronucleus frequency increase or cell viability reduction were observed with the exposure of L-929 murine fibroblast cells to $\mathrm{AgNP} \_\mathrm{SiO}_{2}$ and $\mathrm{TiO}_{2}$ particles at any of the tested concentrations. The non toxic effect of the analyzed particles can be explained by considering its agglomeration tendency, composition, and crystalline form. Further investigations should be done to understand the interference of agglomeration and how it affects the toxicological study.
\end{abstract}

Key words: titanium dioxide, silver, silica, toxicology, mammalian cell

* Author for correspondence: mipittoll@gmail.com 


\section{INTRODUCTION}

For a vast array of commercial and medical applications, nanoscale silver (AgNP) and titanium dioxide $\left(\mathrm{TiO}_{2}\right)$ particles are produced and used in different sizes, shapes, crystalline forms, morphology, surface coating and so forth ${ }^{1,2 .} \mathrm{AgNP}$ is the most used nanoparticle in products manufactured for the marketplace ${ }^{3,4}$. In dermatologic applications (such as aerosols, suspensions and emulsions), $\mathrm{TiO}_{2}$ nanoparticles are the most widely used ${ }^{5,6}$. The growing consumption of these particles is mainly due to their biocide properties ${ }^{7}$. Such widespread use and the production of novel engineered materials raises concerns that the release and exposure to nano and microparticles from loaded materials may pose a risk to human health ${ }^{8}$ and to the environment ${ }^{9}$.

Once the incorporation of nano and micro-sized particles has been widely applied within consumer products, the toxicological evaluation of the potential risks of its chemicals, mainly during the early stages of product development is of interest. Particle characteristics such as shape, chemical composition, capping agent, carrier composition, crystalline form, and surface energy may have an impact on the interaction with cells ${ }^{10}$ and influence the toxic potential ${ }^{2}$. For nanoparticles, as size decreases; increases the ion conductivity on the surface ${ }^{11}$. Also, because of their small size, these particles may enter plant and animals cells and reach critical areas in organelles tissues and organs ${ }^{12}$. Not nanoscale $\mathrm{TiO}_{2}$ is considered to be a non-toxic biocide $^{13,14}$ and its rutile crystal form is recommended as safe to use in cosmetic and pharmaceutical applications ${ }^{15}$.

Reckoning with the above discussions, a range of studies has been performed in normal and cancerous cell trials to determine the role of different particles in toxicity ${ }^{2,16,17,18}$. MTT (3-(4,5-dimethylthiazol-2-yl)-2,5 diphenyltetrazolium bromide) is a metabolic status assay that evaluates reductive capacity of cells ${ }^{19}$. In micronucleus assay the genetic damage is reported by the number of cells containing micronuclei ${ }^{20}$. These pre-screening measurements are useful to provide evidence of the adverse cytotoxicity effects that certain chemicals can cause to living organisms ${ }^{21}$.

The aim of this study is to evaluate the citotoxicity and genotoxicity of silver nanoparticles adsorbed on fumed silica $\left(\mathrm{AgNP}_{-} \mathrm{SiO}_{2}\right)$ and comercial titanium dioxide $\left(\mathrm{TiO}_{2)}\right.$ to mammalian cells.

\section{MATERIALS AND METHODS}

\section{Particle characterization}

The additives nanosilver adsorbed on fumed silica (AgNP_925-SiO, silicon dioxide 98.0-99.4\% and silver 0.1-2.0\%), supplied by TNS Nanotecnologia Ltda., referred to herein as "AgNP_SiO ${ }_{2}$ " and commercial rutile dioxide titanium (TiPure R-103), supplied by DuPont referred to herein as " $\mathrm{TiO}_{2}$ " were used in this study.

The qualitative analysis of mineral composition was determined by X-ray diffraction in a Pan Analytical X'pert PRO and X'PertHigh Score software. Particle size distribution was determined by laser diffraction, and the equipment used was a CILAS 1180 particle size analyzer, with scanning ranging from $0.04 \mu \mathrm{m}$ to $2500 \mu \mathrm{m}$. AgNP_SiO ${ }_{2}$ and $\mathrm{TiO}_{2}$ were predispersed in deionized water using ultrasound for $60 \mathrm{~s}$. To perform morphological analysis by scanning electron microscopy (SEM) the samples were deposited in a carbon type stuck to stub and metalized with gold. For image acquisition was used a SEM of field emission (SEM-FEG) (Inspect F50, FEI) with $20 \mathrm{kV}$, spot 3 and working distance (WD) of $10 \mathrm{~mm}$. Transmission electron microscopy (TEM) was performed at Tecnai, G2 T20 at a voltage of $200 \mathrm{kV}$. The samples were prepared by mounting a drop of the ethanol suspension containing the 
particles on a 300 mesh copper grid carbon film. The average particle diameter and size distribution were calculated using Image $\mathrm{J}$ version $1.40 \mathrm{~g}$ software.

\section{L-929 murine cell line}

L-929 murine fibroblast cell line were purchased from cell bank from Rio de Janeiro Cell Bank, and were grown in the presence of the cell culture medium containing Dulbecco's Modified Eagle's Medium (DMEM- Sigma-Aldrich) (89\%) supplemented with $1 \%$ penicillin/streptomycin (Cultilab) and 10\% fetal calf serum (FCS - Cultilab). The cell was derived from normal subcutaneous areolar and adipose tissue of a 100 day old male mouse.

MTT (3-(4,5-dimethylthiazol-2-yl)-2,5-diphenyltetrazolium bromide) and cytokinesisblock proliferation index (CBPI) assays were performed to identify cytotoxicity effects in L-929 murine fibroblast cells exposed to silver nanoparticle (AgNP_SiO $\left.{ }_{2}\right)$ and titanium dioxide $\left(\mathrm{TiO}_{2}\right)$.

Considering the literature reports connecting the particle size to triggering detrimental effects on mammalian cells and the differences in toxicity values between AgNP and $\mathrm{TiO}_{2}{ }^{22,23}$, different sets of concentration were tested for $\mathrm{AgNP}_{-} \mathrm{SiO}_{2}$ and $\mathrm{TiO}_{2}$ in MTT assay.

\section{MTT (3-(4,5-dimethylthiazol-2-yl)-2,5-diphenyltetrazolium bromide) assay}

The MTT cell proliferation assay was performed according to ISO 10993-5 to evaluate the cytotoxicity of AgNP_SiO${ }_{2}$ and $\mathrm{TiO}_{2}$ particles. The incubation of $\mathrm{AgNP}_{-} \mathrm{SiO}_{2}$ and $\mathrm{TiO}_{2}$ were performed with Mus musculus murine fibroblasts cell line L-929. The particle suspensions were performed in seven concentrations $(15,30,60,120,250$, 500, $1000 \mathrm{ppm} /$ plate) of $\mathrm{AgNP} \_\mathrm{SiO}_{2}$ and of $\mathrm{TiO}_{2}$ dispersed in DMEM (SigmaAldrich). For each particle and concentration, the assay was performed in nine replicates and repeated on two independent experiments. Cells were also treated with doxorubicin (Sigma-Aldrich) in nine different concentrations $(5 ; 2.5 ; 1.25 ; 0.62 ; 0.31$; $0.15 ; 0.07 ; 0.03$ and $0.01 \mu \mathrm{g} / \mathrm{mL}$ as a positive control. Cell suspensions were inoculated onto 96-well cell culture plates at $1 \times 10^{5}$ cells $/ \mathrm{mL}$, incubated in an humidified atmosphere of $5 \% \mathrm{CO}_{2} / 95 \%$ air at $37{ }^{\circ} \mathrm{C}$ for 24 hours to allow for cell adhesion and sedimentation. At the end of period, test metal particles and positive control doxorubicin (Sigma-Aldrich) were incubated with the cells for 24 hours. After the end of the exposure period, a $50 \mu \mathrm{L}$ MTT mixture $(0.5 \mathrm{mg} / \mathrm{mL})$ was added into each well. They were again incubated in a humidified atmosphere of $5 \% \mathrm{CO}_{2} / 95 \%$ air at $37^{\circ} \mathrm{C}$ for 3 hours. Then the MTT mixture was removed and the precipitated formazan was dissolved in isopropyl ethanol.

Absorbance of the formazan product from each well was measured by spectrophotometer (SPECTRA max PLUS 384 Microplate reader, Molecular Devices) at $570 \mathrm{~nm}$. Three controls were set up for each experiment: (1) blank - quality check of assay (phosphate buffered saline - PBS), (2) negative control (cells + DMEM) consisting of $100 \%$ cell viability ${ }^{24}$ and (3) positive control consisting of doxorubicin (Sigma-Aldrich).

In viable cells the yellow tetrazolium salt is reduced by mitochondrial enzymes (succinate dehydrogenase) to a blue water-insoluble formazan product ${ }^{24}$. Citotoxicity values were obtained from the absorbance average $(570 \mathrm{~nm})$ of the replicates in each treatment (concentration) deducted from PBS values and compared to negative control values. Cytotoxicity was categorized according to Dahl et al. ${ }^{25}$, as follow:

- More than $90 \%$ cell viability: not cytotoxic

- 60-90\% cell viability: slightly cytotoxic 
- 30-59\% cell viability: moderately cytotoxic

- Less than 30\% cell viability: severely cytotoxic

\section{Cytokinesis-block proliferation index (CBPI) and micronucleus assay}

Genotoxicity of $\mathrm{AgNP} \_\mathrm{SiO}_{2}$ and $\mathrm{TiO}_{2}$ particles to murine fibroblasts cell was evaluated based on OECD 487 cytokinesis-block proliferation index (CBPI) assay. The CBPI test was performed with Mus musculus murine fibroblasts cell line L-929. Three distinctive concentrations of $\mathrm{AgNP} \_\mathrm{SiO}_{2}$ and $\mathrm{TiO}_{2}$ particles $(15,30,60$ $\mathrm{ppm} / \mathrm{plate}$ ) were tested in CBPI and micronucleus assay. For each particle and concentration, two independent experiments were conducted, each of which performed in triplicate. The dispersion procedure was the same as that used for the MTT assay. Two controls were set up for each experiment: (1) negative control consisting of DMEM medium; and (2) positive control consisting of methyl methanesulfonate (MMS). Incubation was performed with $0.7 \times 10^{5}$ cells $/ \mathrm{mL}$ in a 5 $\mathrm{mL}$ suspension containing DMEM medium (Sigma-Aldrich) (89\%), 1\% penicillin/streptomycin (Cultilab) and $10 \%$ fetal calf serum (Cultilab) in a humidified atmosphere of $5 \% \mathrm{CO}_{2} / 95 \%$ air at $37^{\circ} \mathrm{C}$ for 24 hours.

At the end of the period, the test particles and the positive control MMS $\left(4 \times 10^{-5} \mathrm{M}\right)$ were incubated for 24 and 6 hours respectively. After the end of exposure period, the cells were incubated with cytochalasin B (Sigma-Aldrich) $(3 \mu \mathrm{g} / \mathrm{mL})$ for 42 hours. Then the cells were treated with a hypotonic solution of $\mathrm{KCl} 0.075 \mathrm{M}\left(37^{\circ} \mathrm{C}\right)$ for 15 minutes and fixed in ethanol:acetic acid solution $(3: 1)$ at $4{ }^{\circ} \mathrm{C}$. The slides were covered with the acridine orange staining reagent $(50 \mu \mathrm{g} / \mathrm{mL})$ and examined with fluorescence microscopy (Nikon Eclipse Ni H600L) with a blue light excitation filter $(488 \mathrm{~nm})$ and yellow light emission/barrier $(575 \mathrm{~nm})$ using oil immersion objective.

According to Fenech ${ }^{26}$, only binucleated cells (2000 cells/spot) with intact nuclei, approximately equal scales, and with the same pattern of staining were analyzed. For cytotoxicity evaluation the cytokinesis-block proliferation index (CBPI) was used, which indicates the number of cells with $1,2,3$ or more nuclei in 500 viable cells, calculated in 2 independent assays per treatment.

Genotoxicity was expressed as the average \pm standard error of the percent of micronucleus events per 2000 cells; calculated in two independent assays per treatment.

\section{Statistics analysis}

The results were expressed by average \pm standard error of the mean and significance was obtained through statistical analysis of variance (ANOVA) following the Tukey's test if applicable. For all groups, $\mathrm{p}<0.05$ was considered as being statistically significant.

\section{RESULTS}

\section{Particle characterization}


The results of the X-ray diffraction detected the presence of $\mathrm{SiO}_{2}$ and $\mathrm{Ag}$ in the

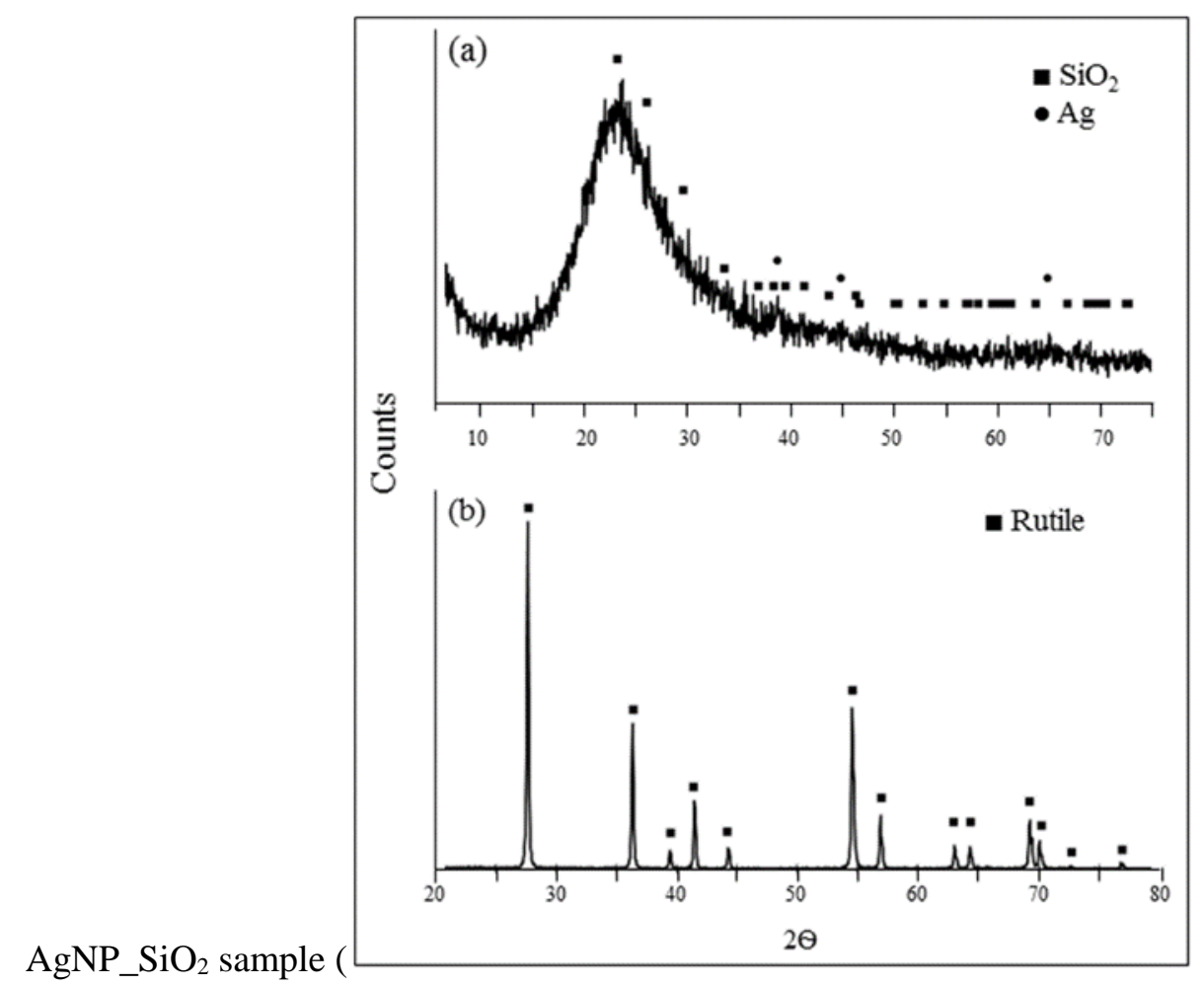

Figure 1A). In accordance with diffractogram results, the $\mathrm{SiO}_{2}$ in this sample was considered amorphous due to no diffraction peaks and a spreading halo with intensity of about $2 \Theta=22^{\circ}$ (characteristic of amorphous materials) ${ }^{27,28}$. The $\mathrm{TiO}_{2}$ sample was confirmed as pure rutile (Figure 1B). 


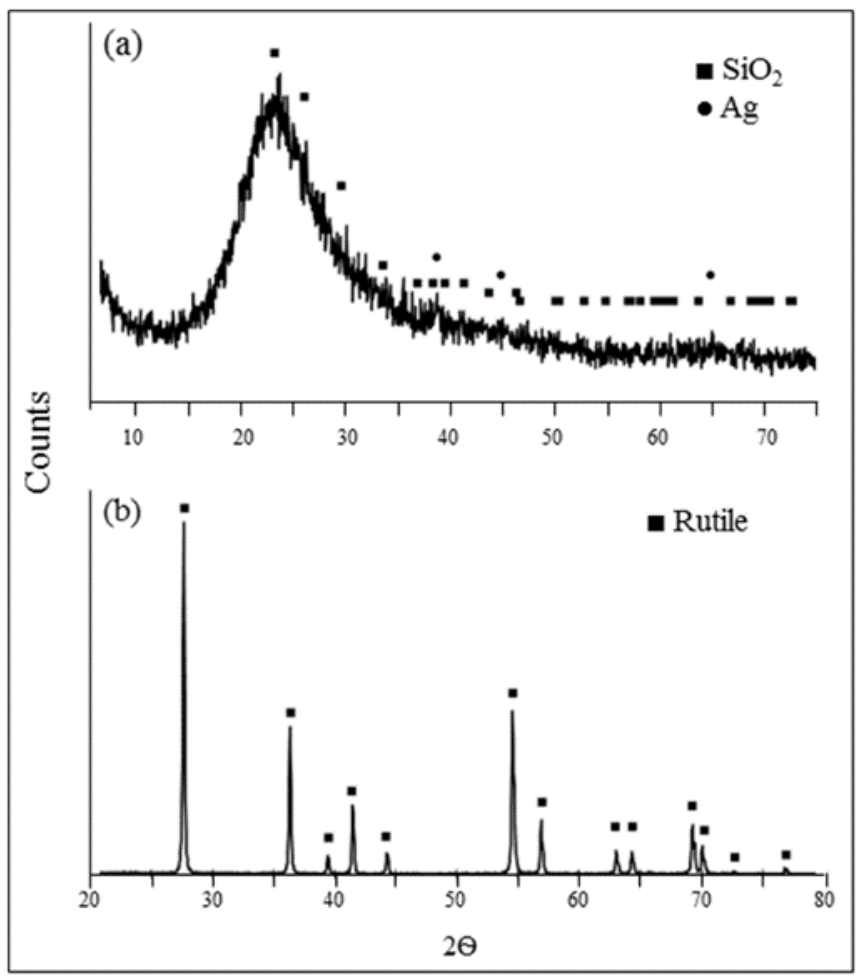

Figure 1- Diffractograms of $\mathrm{AgNP}_{-} \mathrm{SiO}_{2}(\mathrm{~A})$ and $\mathrm{TiO}_{2}(\mathrm{~B})$ samples.

Values of average diameters $\mathrm{D}_{10}, \mathrm{D}_{50}$ and $\mathrm{D}_{90}$ determined by granulometric analysis are shown in Table 1.

Table 1- Values of average diameters $\mathrm{D}_{10}, \mathrm{D}_{50}$ and $\mathrm{D}_{90}$ determined by laser diffraction.

$$
\text { Average diameter, } \quad \mathrm{D}_{10}, \quad \mathrm{D}_{50}, \quad \mathrm{D}_{90},
$$

\begin{tabular}{ccccc} 
& $\mu \mathrm{m}$ & $\mu \mathrm{m}$ & $\mu \mathrm{m}$ & $\mu \mathrm{m}$ \\
\hline $\mathrm{AgNP}_{-} \mathrm{SiO}_{2}$ & 12.97 & 4.7 & 9.2 & 28.99 \\
\hline $\mathrm{TiO}_{2}$ & 0.29 & 0.08 & 0.25 & 0.54 \\
& & & &
\end{tabular}

It was noticed that the average size of the $\mathrm{AgNP} \_\mathrm{SiO}_{2}(12.97 \mu \mathrm{m})$ showed a value above the nanoscale (Table 1 ). This result reflects the size of the aggregates, as observed in SEM and TEM images (Figure 2A and Figure 2B). On SEM images, AgNP_SiO ${ }_{2}$ was observed in the form of blocks with irregular geometry and size, with the same size determined by laser diffraction (between 5 and $30 \mu \mathrm{m}$ ). However, by observing TEM images it was possible to confirm nanoscale of this additive, with nanoparticles of silica $(20 \mathrm{~nm})$ and silver $(10 \mathrm{~nm})$, both in spherical forms (Figure 2B). The $\mathrm{TiO}_{2}$ particles have an average size of $0.29 \mu \mathrm{m}$, but as seen in SEM images (Figure 2C), more particles have nanoscale, and the size determined by laser diffraction reflects the size of agglomerates. As shown in TEM images in Figure 2D, $\mathrm{TiO}_{2}$ is of spherical form and average size of $90 \mathrm{~nm}$.

The results found in laser diffraction and micrograph demonstrated that both additives have nanoscale and high tendency to agglomeration. 

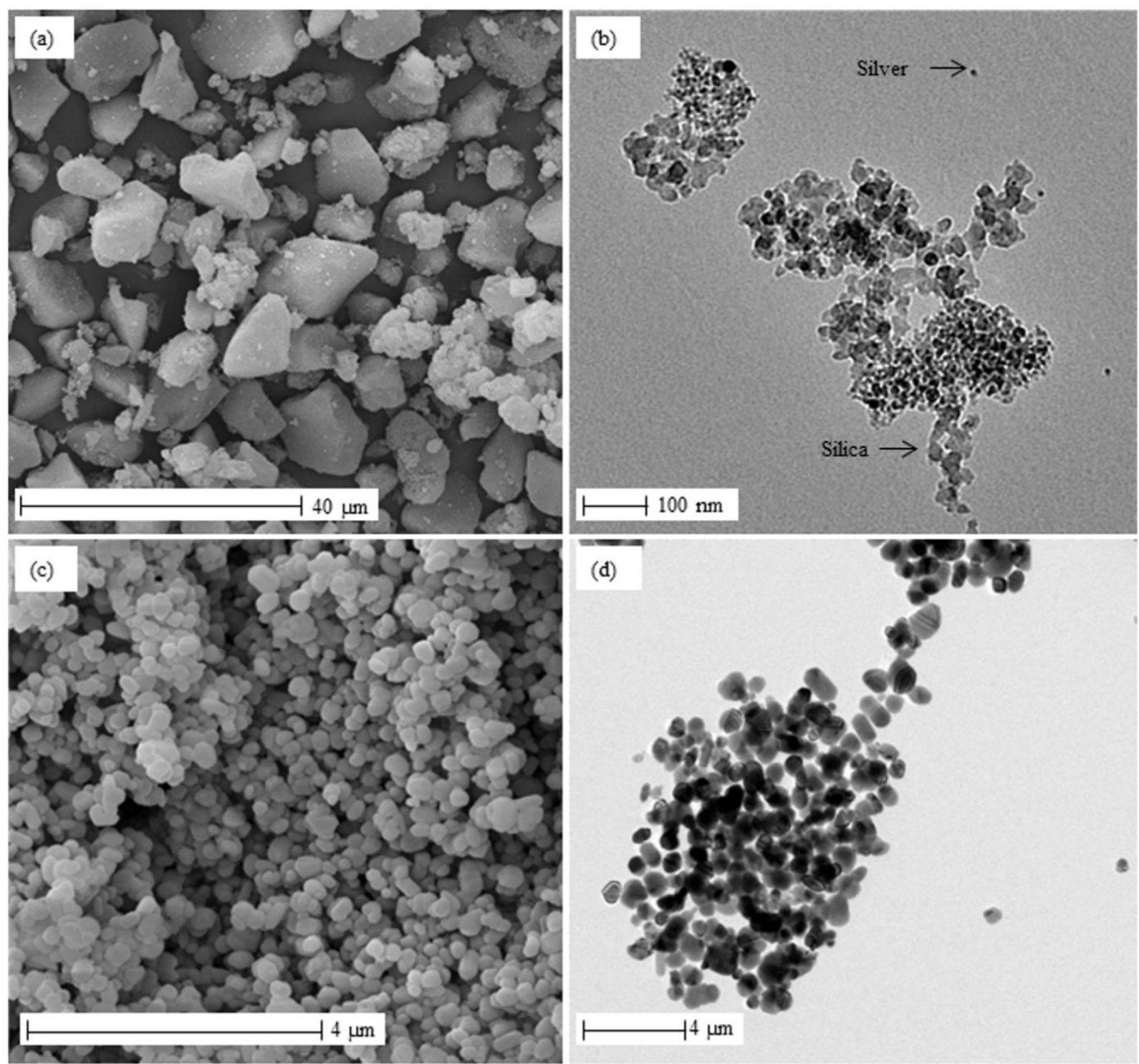

Figure 2- Micrographs of the SEM (left) and TEM (right) additives for (A, B) AgNP_SiO 2 and (C, D) $\mathrm{TiO}_{2}$.

\section{MTT data}

Viability assay expound the cellular reaction to a toxicant ${ }^{12}$. The relation between test chemical (AgNP_SiO 2 and $\mathrm{TiO}_{2}$ ), concentration (ppm) and cell viability (\%) after 24 hour exposures using the MTT assay are presented in Figure 3. 


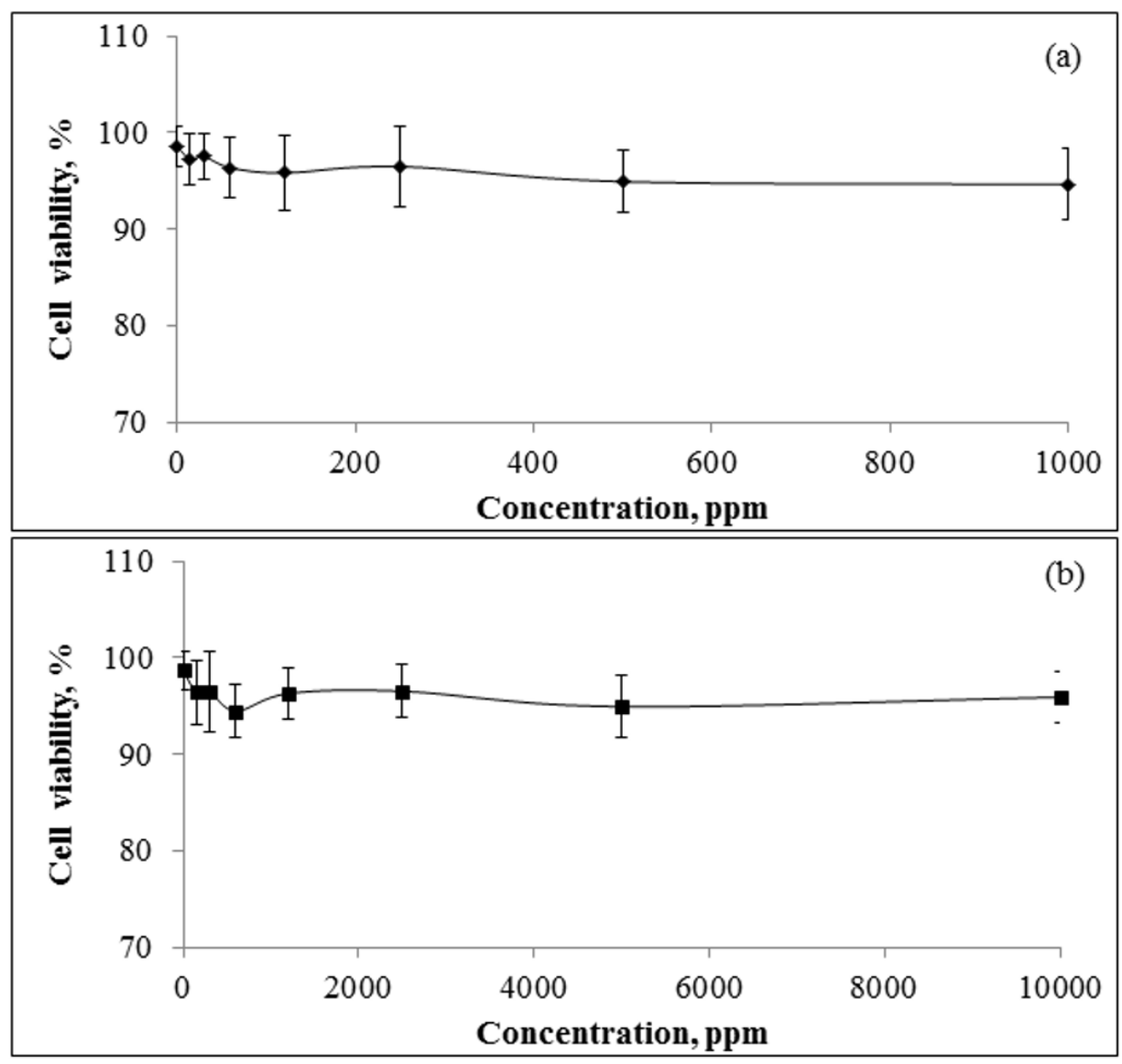

Figure 3- Cell viability of L-929 murine fibroblast after $24 \mathrm{~h}$ of exposure to distinctive concentrations of (A) AgNP_SiO ${ }_{2}$ and (B) $\mathrm{TiO}_{2}$ by MTT method. Each point represents the mean and standard deviation in nine replicates.

The viability of the cells exposed to AgNP_SiO 2 was significantly different $(\mathrm{p}<0.05)$ between the tested additive concentrations. In cell exposed to $\mathrm{TiO}_{2}$ particles there was no difference between the concentrations of the additives. Since cell viability values were between 95.83 - 97.53 in the presence of $\mathrm{AgNP}_{2} \mathrm{SiO}_{2}$ (Figure 3A) and 94.47 96.54 in cells treated with $\mathrm{TiO}_{2}$ (Figure $3 \mathrm{~B}$ ), according to cell viability classification and the experimental conditions performed in this study, the $\mathrm{AgNP} \_\mathrm{SiO}_{2}$ and $\mathrm{TiO}_{2}$ particles were classified as non cytotoxic.

\section{CBPI and micronucleus data}

The experimental data for CBPI values and micronucleus frequency are summarized in Table 2. With data presented as mean values \pm standard deviations. The experiment was conducted following $24 \mathrm{~h}$ exposure time.

No significant cell viability reduction was observed on murine cells treated with AgNP_SiO ${ }_{2}$ and $\mathrm{TiO}_{2}$. There were no concentration-dependent increases in micronucleus frequency on murine cells treated with $\mathrm{AgNP}_{-} \mathrm{SiO}_{2}$ and $\mathrm{TiO}_{2}(\mathrm{Table} 2)$. 
Table 2- CBPI values and micronucleus frequency of L-929 murine fibroblasts cells treated with $\mathrm{AgNP}_{-} \mathrm{SiO}_{2}$ and $\mathrm{TiO}_{2}$ samples.

\begin{tabular}{|c|c|c|}
\hline \multirow{3}{*}{ Treatment } & \multicolumn{2}{|c|}{ Assay } \\
\hline & \multicolumn{2}{|c|}{$\mathrm{CBPI}^{\mathrm{c}}$} \\
\hline & AgNP_SiO ${ }_{2}$ & $\mathrm{TiO}_{2}$ \\
\hline $\mathrm{NC}^{\mathrm{a}}$ & $1.67 \pm 0.016$ & $1.67 \pm 0.016$ \\
\hline $\mathrm{PC}^{\mathrm{b}}$ & $1.11 \pm 0.023$ & $1.11 \pm 0.023$ \\
\hline $15 \mathrm{ppm}$ & $1.66 \pm 0.020$ & $1.65 \pm 0.009$ \\
\hline 30 ppm & $1.64 \pm 0.010$ & $1.66 \pm 0.008$ \\
\hline \multirow[t]{3}{*}{60 ppm } & $1.65 \pm 0.008$ & $1.68 \pm 0.008$ \\
\hline & \multicolumn{2}{|c|}{$\mathrm{MN}^{\mathrm{d}}$} \\
\hline & AgNP_SiO ${ }_{2}$ & $\mathrm{TiO}_{2}$ \\
\hline $\mathrm{NC}^{\mathrm{a}}$ & $0.15 \pm 0.050$ & $0.15 \pm 0.050$ \\
\hline $\mathrm{PC}^{\mathrm{b}}$ & $3.35 \pm 0.124$ & $3.35 \pm 0.124$ \\
\hline $15 \mathrm{ppm}$ & $0.17 \pm 0.042$ & $0.17 \pm 0.042$ \\
\hline 30 ppm & $0.20 \pm 0.035$ & $0.20 \pm 0.035$ \\
\hline 60 ppm & $0.10 \pm 0.033$ & $0.10 \pm 0.033$ \\
\hline
\end{tabular}

${ }^{\mathrm{a}}$ negative control (DMEM), ${ }^{\mathrm{b}}$ positive control (MMS, $\left.4 \times 10^{-5} \mathrm{M}\right)$, ${ }^{\mathrm{c}}$ cytokinesis-block proliferation index (CBPI) 500 cells analyzed, ${ }^{\mathrm{d}}$ micronucleus (MN) 2000 cells analyzed

\section{DISCUSSION}

The viability of L929 murine cell was found to be greater than $90 \%$, even in the highest concentrations used in $\mathrm{NpAg} \_S i O_{2}$ (average size - 10-20 nm; $1000 \mathrm{ppm}$ ) and $\mathrm{TiO}_{2}$ (average size - $90 \mathrm{~nm} ; 10000 \mathrm{ppm}$ ) tests. In contrast to our findings, cytotoxic and genotoxic studies have shown harmful effects of nanosized ( 0.1 to $100 \mathrm{~nm}) \mathrm{Ag}$ and $\mathrm{TiO}_{2}$ particles to mammals' cells ${ }^{12}$. A variety of scales and concentrations have been assigned to the $\mathrm{AgNP}^{22,29,30}$ and $\mathrm{TiO}_{2}$ toxicity values ${ }^{23,31,32}$. In a cytokinesis blocked micronucleus assay, DNA damage and significant numbers of micronuclei were observed in human fibroblast and human cancer cells after the treatment with AgNP $(6-20 \mathrm{~nm})^{12}$. In a research conducted by Li et al. ${ }^{33}$ the AgNP $(5 \mathrm{~nm})$ particle induced significant increase in micronucleus frequency over the control. Carlson et al. ${ }^{34}$ observed in $24 \mathrm{~h}$ MTT study a decrease of $88.66 \%$ in mitochondrial function of alveolar macrophages exposed to $\operatorname{AgNP}(15 \mathrm{~nm})$ at concentrations of $50 \mu \mathrm{g} / \mathrm{mL}$. However, bigger AgNP (55 nm) exhibit a viability decrease of $33.89 \%$ at the highest dose $(75 \mathrm{ppm})$ and AgNPs $(5-40 \mathrm{~nm})$ in a concentration up to $100 \mathrm{ppm}$ can be used as a drug delivery ${ }^{18}$. These above reports showed a variable degree of $\mathrm{AgNP}$ and $\mathrm{TiO}_{2}$ toxicity, highlighting the complexity of the study of nanomaterials, emphasized by the diversity of the evaluated cells. 
Concerns associated to nanoparticles are the metal ions released from the material ${ }^{9}$, as well as their larger surface area, that enhance the interaction with cells ${ }^{35}$, and the small size, that allows for easier penetration into the cells ${ }^{36,37}$. Although the engineering of NPs internalization into cells is considered as non-specific according to studies with microcopy images ${ }^{38}$, endocytosis is an important mechanism to $\mathrm{Ag}^{39}$ and $\mathrm{TiO}_{2}$ nanoparticles ${ }^{40}$ cell intake. However, particle agglomeration can mitigate the toxic effects of particle size, which may vary depending on cell type and internalization mechanisms ${ }^{41,42}$. In this study, micrographs and granulometric analysis show that AgNP_SiO ${ }_{2}$ and $\mathrm{TiO}_{2}$ present a tendency to agglomerate, with a set size of $12.97 \mu \mathrm{m}$ and $0.29 \mu \mathrm{m}$, respectively. It is recognized that at the cellular level, size will have an impact on particle uptake ${ }^{43}$. In this way, as reported by Sambale et al. ${ }^{22}$ non nanomaterial (above $0.1 \mu \mathrm{m}$ ) may prevent the cell apoptosis by diminishing access and penetration of particles into the cytoplasm, also the microparticles do not dissolve as rapidly as nanoscale ones, providing a slow release of metal, particularly around the nucleus of the cell ${ }^{44}$.

The AgNP_SiO ${ }_{2}$ presents the silica covering a range of $98.0-99.4 \%$ of the total particles (data provided by the suppliers). According to X-Ray diffraction, this silica is amorphous. Silica on amorphous structure is considered non toxic ${ }^{45,46}$, also when silver nanoparticles are deposited on a silica carrier, the hydrophilicity characteristics of silica reduces the nonspecific binding of proteins ${ }^{47}$ and the release of $\mathrm{AgNP}^{48}$ leading to lower toxicity ${ }^{49}$. In a previous study, cell culture condition was shown to influence the toxicity of amorphous silica. Drescher and coworkers ${ }^{50}$ observed an agglomeration tendency of silica nanoparticles in all FCS-containing medium, the same supplement used in this study, and this condition caused a decrease in toxicity. Such behavior may be explained by the organic components of treatment media ${ }^{51}$, considering that the adsorption of serum proteins into silica surface can change particle compatibility, membrane contact and uptake into the cells ${ }^{52}$. Although micronucleus (MN) test has been considered more appropriate for evaluating the genotoxicity of the $\mathrm{AgNP}^{33}$, there is an issue pertaining the use of cytochalasin $\mathrm{B}$ in MN assay. The addition of this chemical could mask the real cytotoxicity of a tested substance ${ }^{44,53,54}$, by restricting particle uptake due the phagocytosis inhibition ${ }^{55}$. The alternative assays to access genotoxicity of nano and microparticles would be the Ames test and Comet assay ${ }^{56}$. However, in the case of this study, that evaluated the toxicity of known antimicrobial particles, the Ames test may not be a suitable option because its test uses bacterial cells for determining mutagenicity ${ }^{57}$.

The uptake of small clusters by cells is more efficient than the uptake of larger clusters $^{58}$ and the presence of FCS in the MTT assay and cytochalasin B in MN test was shown to influence the formation of aggregates and therefore, may have an impact on the dispersion and bioavailability of the particles ${ }^{59}$. Thus, the non toxic effect of AgNP_SiO 2 and $\mathrm{TiO}_{2}$ observed in our experimental conditions could be related to the agglomeration tendency of the tested particles ${ }^{59,60}$, amplified by the contribution of treatment conditions used in the assay on the agglomeration and cell input mechanisms. Moreover, the $\mathrm{TiO}_{2}$ rutile morphology is described as a less photocatalyst ${ }^{61}$ and non-cytotoxic ${ }^{15,62}$ form of $\mathrm{TiO}_{2}$ crystal $^{63}$.

The murine fibroblast cell line L-929 used in this study is a suitable cell type for the investigation of in vitro toxicity of the metal particles, being routinely used for this purpose due its biological response, reproducible growth rates and facility in the cell culture conditions ${ }^{64,65}$. However, with respect to the sensitivity, this cell line were found to be resistant to plant extracts ${ }^{66}$, but also sensitive to other substances ${ }^{64,67}$. In summary, it seems that apart of cell line, the elements that control nanoparticles cytotoxic responses vary depending on the concentration, size and type of material tested as well as the assay system. Mahmoudi and coworkers (2009) ${ }^{68}$ reported enhancement of mitosis and apoptosis phenomena in $\mathrm{G}_{0} / \mathrm{G}_{1}$ phase after the exposure of 
fibroblast cell to iron oxide nanoparticles. Also, cellular damage and DNA deterioration was reported upon the exposure to $\mathrm{TiO}_{2}{ }^{40}$ and $\mathrm{Ag}$ nanoparticles ${ }^{69}$, and the concentration of these nanoparticles was reported inside mitochondria, nucleus and nucleolus ${ }^{12}$.

At this point, it can be speculated that the manner in which the particle is presented to the cell in terms of supporting elements (e.g. $\mathrm{SiO}_{2}$ ), crystal form, particle and agglomerate sizes, as well as the treatment medium conditions could be the factors handling this toxicological study. Additionally, the comparison of our results with others was hampered due to miscellaneous methods, concentrations, cell types and mainly the characteristics of the materials used in previous toxicological inventories. Due to the diversity of structural components, the committee on emerging and newly identified health risks - SCENIHR ${ }^{70}$ advocates that the toxicological assessment of novel materials (such as $\mathrm{AgNP} \_\mathrm{SiO}_{2}$ ) should be done on a case-by-case basis.

\section{CONCLUSION}

The particles AgNP_SiO ${ }_{2}$ and $\mathrm{TiO}_{2}$ did not cause citotoxicity and genotoxicity detectable by MTT and CBPI tests in L-929 murine fibroblast cell at any tested concentration. The non toxic effect of the analyzed particles can be explained by considering its agglomeration tendency, supporting element, and crystalline form, together with their interaction in culture media. Clearly, further investigations are needed to better understand the cyto/genotoxicity mechanisms of $\mathrm{AgNP}_{-} \mathrm{SiO}_{2}$ and $\mathrm{TiO}_{2}$ in cultured mammalian cells.

\section{REFERENCES}

1- Dankovic D, Kuempel E, Wheeler M. An approach to risk assessment for $\mathrm{TiO}_{2}$. Inhal Toxicol. 2007; 19:205-212.

2- Gatoo MA, Naseem S, Arfat MY, Dar AM, Qasim K, Zubair S. Physicochemical properties of nanomaterials: implication in associated toxic manifestations. Biomed Res Int. 2014; 2014: 498420.

3- Brunetti G, Donner E, Laera G, Sekine R, Scheckel KG, Khaksar M, Vasilev K, Mastro GD, Lombi E. Fate of zinc and silver engineered nanoparticles in sewerage networks. Water Res. 2015; 77:72-84.

4-Vance ME, Kuiken T, Vejerano EP, McGinnis SP, Hochella MFJ, Rejeski D, Hull MS. Nanotechnology in the real world: redeveloping the nanomaterial consumer products inventory. Beilstein J Nanotechnol. 2015; 6: 1769-1780.

5- Nel A, Xia T, Mädler L, Li N. Toxic potential of materials at the nanolevel. Science. 2006; 311:622-627.

6- Natarajan V, Wilson CL, Hayward SL, Kidambi S. Titanium dioxide nanoparticles trigger loss of function and perturbation of mitochondrial dynamics in primary hepatocytes. Plos One. 2015; 10: e0134541.

7- Chernousova S, Epple M. Silver as antibacterial agent: ion, nanoparticle, and metal. Angew Chem Int. 2013; 52:1636-1653.

8- Zhang R, Bai Y, Zhang B, Chen L, Yan B. The potential health risk of titania nanoparticles. J Hazard Mater.2012; 211-212: 404- 413.

9- Beer C, Foldbjerg R, Hayashi Y, Sutherland DS, Autrup H. Toxicity of silver nanoparticles Nanoparticle or silver ion? Toxicol Lett. 2012; 208:286-92.

10- Navya, PN, Daima, HK. Rational engineering of physicochemical properties of nanomaterials for biomedical applications with nanotoxicological perspectives. Nano Convergence. 2016; 3:1.

11- Tamaki T, Nakanishi N, Ohashi H, Yamaguchi T. The effect of particle size and surface area on the ion conductivity of layered double hydroxide. Electrochem Commun. 2012; 25:5053. 
12- Asharani PV, Mun GLK, Hande MP, Valiyaveettil S. Cytotoxicity and genotoxicity of silver nanoparticles in human cells. ACS Nano. 2009; 3:279-90.

13- Bermudez E, Mangum JB, Asgharian B, Wong BA, Reverdy EE, Janszen DB. Long-term pulmonary responses of three laboratory rodent species to subchronic inhalation of pigmentary titanium dioxide particles. Toxicol Sci. 2002; 70:86-97.

14 - Rosa ELS. Kinetic effects of $\mathrm{TiO}_{2}$ fine particles and nanoparticles aggregates on the nano mechanical properties of human neutrophils assessed by force spectroscopy. BMC Biophys. 2013; 6:11.

15-Turci F, Peira E, Corazzari I, Fenoglio I, Trotta M, Fubini B. Crystalline phase modulates the potency of nanometric $\mathrm{TiO}_{2}$ to adhere to and perturb the stratum corneum of porcine skin under indoor light. Chem Res Toxicol. 2013; 26: 1579-1590.

16 - Barkhordari A, Barzegar S, Hekmatimoghaddam H, Jebali A, Moghadam SR, Khanjani N. The toxic effects of silver nanoparticles on blood mononuclear cells. Int J Occup Environ Health. 2014; 5:164-168.

17 - Zhang T, Wang L, Chen Q, Chen C. Cytotoxic potential of silver nanoparticles. Yonsei Med J. 2014; 55:283-291.

18 - Kulandaivelu B, Gothandam KM. Cytotoxic Effect on Cancerous Cell Lines by Biologically Synthesized Silver Nanoparticles. Braz Arch Biol Technol. 2016;59: e16150529.

19- Abe K, Matsuki N. Measurement of cellular 3-(4,5-dimethylthiazol-2-yl)-2,5diphenyltetrazolium bromide (MTT) reduction activity and lactate dehydrogenase release using MTT. Neurosci Res. 2000; 38:325-29.

20- Kirsch-Volders M, Decordier I, Elhajouji A, Plas G, Aardema MJ, Fenech M. In vitro genotoxicity testing using the micronucleus assay in cell lines, human lymphocytes and 3D human skin models. Mutagenesis. 2011; 26:177-184.

21- Dechsakulthorn F, Hayes A, Bakand S, Joeng L, Winder C. In vitro cytotoxicity assessment of selected nanoparticles using human skin fibroblastos. AATEX 2007;14: 397-400. 22 - Sambale F, Wagner S, Stahl F, Khaydarov RR, Scheper T, Bahnemann D. Investigations of the toxic effect of silver nanoparticles on mammalian cell lines. J Nanomater. 2015; 2015: 136765 .

23- Uboldi C, Urbán P, Gilliland D, Bajaka E, Valsami-Jones E, Ponti J, Rossi F. Role of the crystalline form of titanium dioxide nanoparticles: Rutile, and not anatase, induces toxic effects in Balb/3T3 mouse fibroblasts. Toxicol In Vitro. 2016; 31:137-145.

24- Mosmann T. Rapid colorimetric assay for cellular growth and survival: application to proliferation and cytotoxicity assay. J Immunol Methods. 1983; 65: 55-63.

25- Dahl JE, Frangou-Polyzois MJ, Polyzois GL. In vitro biocompatibility of denture relining materials. Gerodontology. 2006; 23:17-22.

26 - Fenech M. Cytokinesis-block micronucleus cytome assay. Nat Protoc. 2007; 2: 10841104.

27- Barazani B. Investigação sobre a sinterização de sílica vítrea por plasma pulsado. São Paulo: Escola Politécnica da Universidade de São Paulo; 2011.

28-Zanoteli K, Freitas JCC, Silva, PRND. Estudo de catalisadores de níquel suportados em cinza de casca de arroz na reforma de metano com dióxido de carbono visando a produção de hidrogênio e gás de síntese [Study of nickel catalysts supported on rice husk ash in reforming of methane with carbon dioxide in order to produce hydrogen and synthesis gas]. Quim Nova. 2014; 37:1657-1662.

29-Haase A, Arlinghaus HF, Tentschert J, Jungnickel H, Graf P, Mantion A, Draude F, Galla S, Plendl J, Goetz ME, Masic A, Meier W, Thüunemann AF, Taubert A, Luch A. Application of laser postionization secondary neutral mass spectrometry/time-of-flight secondary ion mass spectrometry in nanotoxicology: visualization of nanosilver in human macrophages and cellular responses. ACSNano. 2011; 5:3059-3068.

30-Hackenberg S, Scherzed A, Kessler M, Hummel S, Technau A, Froelich K, Ginzkey C, Koehler C, Hagen R, Kleinsasser N. Silver nanoparticles: Evaluation of DNA damage, toxicity and functional impairment in human mesenchymal stem cells. Toxicol Lett. 2011; 195: 9-14.

31- Trouiller B, Reliene R, Westbrook A, Solaimani P, Schiestl RH. Titanium dioxide nanoparticles induce DNA damage and genetic instability in vivo in mice. Cancer Res. 2009; 69: 8784-8789. 
32- Ghosh M, Chakraborty A, Mukherjee A. Cytotoxic, genotoxic and the hemolytic effect of titanium dioxide $\left(\mathrm{TiO}_{2}\right)$ nanoparticles on human erythrocyte and lymphocyte cells in vitro. $J$ Appl Toxicol. 2013; 33: 1097-1110.

33- Li Y, Chen DH, Yan J, Chen Y, Mittelstaedt RA, Zhang Y, Biris AS, Heflich RH, Chen T. Genotoxicity of silver nanoparticles evaluated using the Ames test and in vitro micronucleus assay. Mutat Res. 2012; 745:4-10.

34- Carlson C, Hussain SM, Schrand AM, Braydich-Stolle LK, Hess KL, Jones RL, Schlager JJ. Unique cellular interaction of silver nanoparticles: size-dependent generation of reactive oxygen species. J Phys Chem B. 2008; 112:13608-13619.

35- Kalbassi MR, Johari SA, Soltani M, Yu IJ. Particle size and agglomeration affect the toxicity levels of silver nanoparticle types in aquatic environment. Ecopersia. 2013; 1: 273290.

36- Mudunkotuwa IA, Grassian VH. The devil is in the details (or the surface): impact of surface structure and surface energetics on understanding the behavior of nanomaterials in the environment. J Environ Monit. 2011; 13: 1135-44.

37- Bian SW, Mudunkotuwa IA, Rupasinghe T, Grassian VH. Aggregation and dissolution of $4 \mathrm{~nm} \mathrm{ZnO}$ nanoparticles in aqueous environments: influence of $\mathrm{pH}$, ionic strength, size, and adsorption of humic acid. Langmuir. 2011; 27:6059-68.

38- Gao H, Yang Z, Zhang S, Cao S, Shen S, Pang Z, Jiang X. Ligand modified nanoparticles increases cell uptake, alters endocytosis and elevates glioma distribution and internalization. Scientific reports. 2013; 3:2534.

39- Wang H, Wu L, Reinhard BM. Scavenger Receptor Mediated Endocytosis of Silver Nanoparticles into J774A.1 Macrophages is Heterogeneous. ACS Nano. 2012; $28 ; 6(8): 7122-7132$.

40- Jin C-Y, Zhu B-S, Wang X-F, Lu Q-H. Cytotoxicity of Titanium Dioxide Nanoparticles in Mouse Fibroblast Cells. Chem. Res. Toxicol. 2008; 21:1871-1877.

41- Albanese A, Chan WCW. Effect of gold nanoparticle aggregation on cell uptake and toxicity. ACS Nano. 2011; 5:5478-89.

42- Bernier MC, Kirat KE, Besse M, Morandat S, Vayssade M. Preosteoblasts and fibroblasts respond differently to anatase titanium dioxide nanoparticles: A cytotoxicity and inflammation study. Colloids Surf B: Biointerfaces. 2012; 90:68-74.

43- Huang X, Young NP, Townley HE. Characterization and comparison of mesoporous silica particles for optimized drug delivery. Nanomater Nanotechno. 2014; 4:2.

44- Papageorgiou I, Brown C, Schins R, Singh S, Newson R, Davis S, Fisher J, Ingham E, Case CP. The effect of nano- and micron-sized particles of cobalt-chromium alloy on human fibroblasts in vitro. Biomaterials. 2007; 28:2946-58.

45- Brunner TJ, Wick P, Manser P, Spohn P, Grass RN, Limbach LK, Bruinink A, Stark WJ. In vitro cytotoxicity of oxide nanoparticles: comparison to asbestos, silica, and the effect of particle solubility. Environ. Sci. Technol. 2006, 40, 4374-4381.

46- Barnes CA, Elsaesser A, Arkusz J, Smok A, Palus J, Lesniak A, Salvati A, Hanrahan JP, Jong WH, Dziubałtowska E, Stepnik M, Rydzynski K, McKerr G, Lynch I, Dawson KA, Howard CV. Reproducible comet assay of amorphous silica nanoparticles detects no genotoxicity. Nano Lett. 2008; 8:3060-3074.

47- Hu L, Fawcett JP, Gu J. Protein target discovery of drug and its reactive intermediate metabolite by using proteomic strategy. Acta Pharm Sin B. 2012; 2:126-136.

48- Agnihotri S, Mukherji S, Mukherji S. Immobilized silver nanoparticles enhance contact killing and show highest efficacy: elucidation of the mechanism of bactericidal action of silver. Nanoscale. 2013; 5:7328-40.

49- Hu SH, Liu TY, Huang HY, Liu DM, Chen SY. Magnetic-sensitive silica nanospheres for controlled drug release. Langmuir. 2008; 24: 239-244.

50- Drescher D, Orts-Gil G, Laube G, Natte K, Veh RW, Österle W, Kneipp J. Toxicity of amorphous silica nanoparticles on eukaryotic cell model is determined by particle agglomeration and serum protein adsorption effects. Anal Bioanal Chem. 2011; 400:1367-73.

51- Lynch I, Dawson KA. Protein-nanoparticle interactions. Nanotoday. 2008; 3: 40-47.

52- Stayton I, Winiarz J, Shannon K, Ma Y. Study of uptake and loss of silica nanoparticles in living human lung epithelial cells at single cell level. Anal Bioanal Chem. 2009; 394:15951608 . 
53- Kim HR, Kim MJ, Lee SY, Oh SM, Chung KH. Genotoxic effects of silver nanoparticles stimulated by oxidative stress in human normal bronchial epithelial (BEAS-2B) cells. Mutat Res. 2011; 726:129-135.

54- Kim HR, Park YJ, Shin DY, Oh SM, Chung KH. Appropriate in vitro methods for genotoxicity testing of silver nanoparticles. Environ Health Toxicol. 2013; 28: e2013003.

55- Falck GCM, Lindberg HK, Suhonen S, Vippola M, Vanhala E, Catalán J, Savolainen K, Norppa H. Genotoxic effects of nanosized and fine $\mathrm{TiO}_{2}$. Hum Exp Toxicol. 2009; 28: 339-52.

56- Woodruff RS, Li Y, Yan J, Bishop M, Jones MY, Watanabe F, Biris AS, Rice P, Zhouf T, Chenb T. Genotoxicity evaluation of titanium dioxide nanoparticles using the Ames test and Comet assay. J. Appl. Toxicol. 2012; 32: 934-943.

57- Clift MJD, Raemy DO, EndesC, Ali Z, Lehmann AD, Brandenberger C, Petri-Fink A, Wick P, Parak WJ, Gehr P, Schins RPF, Rothen-Rutishauser B. Can the Ames test provide an insight into nano-object mutagenicity? Investigating the interaction between nano-objects and bacteria. Nanotechnology. 2013; 7(8): 1373-1385.

58- Chithrani BD, Ghazani AA, Chan WCW. Determining the size and shape dependence of gold nanoparticle uptake into mammalian cells. Nano Lett. 2006; 6:662-8.

59- Murdock RC, Braydich-Stolle L, Schrand AM, Schlager JJ, Hussain SM. Characterization of nanomaterial dispersion in solution prior to in vitro exposure using dynamic light scattering technique. Toxicol Sci. 2008; 101:239-253.

60- Ates M, Daniels J, Arslan Z, Farah IO. Effects of aqueous suspensions of titanium dioxide nanoparticles on Artemia salina: assessment of nanoparticle aggregation, accumulation, and toxicity. Environ Monit Assess. 2013; 185:3339-48.

61- Kakinoki K, Yamane K, Teraoka R, Otsuka M, Matsuda Y. Effect of relative humidity on the photocatalytic activity of titanium dioxide and photostability of famotidine. J Pharm Sci. 2004; 93: 582-589.

62- Sayes CM, Wahi R, Kurian PA, Liu Y, West JL, Ausman KD, Warheit DB, Colvin VL. Correlating nanoscale titania structure with toxicity: a cytotoxicity and inflammatory response study with human dermal fibroblasts and human lung epithelial cells. Toxicol Sci. 2006; 92:174-185.

63- Warheit DB, Webb TR, Reed KL, Frerichs S, Sayes CM. Pulmonary toxicity study in rats with three forms of ultrafine- $\mathrm{TiO}_{2}$ particles: Differential responses related to surface properties. Toxicology. 2007; 230: 90-104.

64- Schedlel A, Samorapoompichit P, Rausch-Fan XH, Franz A, Fureder W, Sperr WR, Sperr W, Ellingerl A, Slavicek R, Boltz-Nitulescu G, Valent P. Response of L-929 Fibroblasts, Human Gingival Fibroblasts, and Human Tissue Mast Cells to Various Metal Cations. J. Dent. Res. 1995; 74(8): 1513-1520.

65- International Organization for Standardization. ISO 10993-5: Biological evaluation of medical devices - Part 5: Tests for in vitro cytotoxicity. 2009, Switzerland.

66- Nascimento FG, Faqueti A, Wilhelm JF, Wittkowski C, Tomczak FD, Borges SL, Yunes RA, Franchi Jr. GC, Nowill AE, Filho VC, Machado MS, Freitas RA, Malheiros A. Seasonal influence and cytotoxicity of extracts, fractions and major compounds from Allamanda schottii. Rev. Bras. Farmacogn. 2014; 24: 545-552.

67- Thonemann B, Schmalz G, Hiller KA, Schweik H. Responses of L929 mouse fibroblasts, primary and immortalized bovine dental papilla-derived cell lines to dental resin components. Dent. Mater. 2002; 18(4): 318-323.

68- Mahmoudi M, Simchi A, Vali H, Imani M, Shokrgozar MA, Azadmanesh K, Azari F. Cytotoxicity and Cell Cycle Effects of Bare and Poly(vinylalcohol)-Coated Iron Oxide Nanoparticles in Mouse Fibroblasts. Adv. Eng. Mater. 2009; 11(12): B243-B250.

69- Ahamed M, Karns M, Goodson M, Rowe J, Hussain SM, Schlager JJ, Hong Y. DNA damage response to different surface chemistry of silver nanoparticles in mammalian cells. Toxicol. Appl. Pharm. 2008; 233: 404-410.

70- SCENIHR. (Scientific Committee on Emerging and Newly Identified Health Risks). Risk assessment of products of nanotechnologies. Brussels: European Commission, 2009. Available at http://ec.europa.eu/health/ph_risk/committees/04_ scenihr/docs/scenihr_ o_023.pdf. Accessed 8/Dec/2015. 